\title{
Examining the Role of Service Quality in Relationship Quality Creation: Empirical Insights from Malaysia
}

\author{
Jalal Hanaysha \\ Corresponding Author, Doctoral Scholar, College of Business, Universiti Utara Malaysia \\ Email: jalal.hanayshi@yahoo.com \\ Haim Hilman \\ Associate Professor, College of Business, Universiti Utara Malaysia \\ Email: hilman@uum.edu.my
}

\section{Doi:10.5901/mjss.2015.v6n4p458}

\begin{abstract}
Building and maintaining successful relationships with customers have become the prime focus for many organizations. The ability of a brand to manage customer relationships in a favourable manner provides a strong platform for its continued success. This paper examines the effect of service quality on relationship quality in the Malaysian automobile market. The data was collected using systematic sampling from 287 passenger car users' at shopping malls in Northern region of Malaysia. The data is analyzed using structural equation modeling on AMOS. The results revealed that service quality has significant positive effect on brand trust, brand commitment, and brand satisfaction. The results also indicated that service quality has significant positive effect on overall relationship quality. Because this study is limited only to individual customers in Northern region of Malaysia, future studies might apply this work to organizational level and expand it to other industry and country contexts for better understandings of how service quality can affect customer relationships. As a result of successful customer relationships, organizations would have greater opportunities to sustain their success and respond to competition.
\end{abstract}

Keywords: Relationship quality, brand commitment, brand satisfaction, brand trust, service quality, automotive industry.

\section{Introduction}

In increasingly competitive environments, organizations are continuously looking for the relevant strategies to ensure their survival in such competitive phenomenon and drive their long-term success. Apart from these strategies is the focus on enhancing service quality and fostering customers' relationships. Relationship quality has received tremendous attention from business managers and academicians due to its significant effect on business performance and profitability (Morgan \& Hunt, 1994). In particular, the investment in quality aspects is considered to be the main strength of an organization; this because the efforts for its enhancement would result in an enlarged clientele, greater levels of purchase consumption from customers, and higher growth of profits (Hilman \& Hanaysha, 2015).

Service quality has established its substance in literature for the last many years. Based on the review of literature, it is evident that most of the earlier efforts in measuring this concept were centred in service sectors, while in the manufacturing context, studies on the consequences of service quality are limited. Moreover, the majority of past studies on service quality examined its effect on customer satisfaction and loyalty. But very limited empirical work is intended to test its effect on relationship quality; brand trust, brand commitment, and brand satisfaction. Tey, Brindal, Fatimah, Kusairi, Ahmad Hanis and Suryani (2014) declared that there are limited studies that examined the effect of service quality on relationship quality elements such as commitment. The review of literature also shows that most of the studies on this concept were conducted in western countries and only little empirical work was done in Asian contexts. Therefore, to explore our knowledge in this area, the present study aims to examine the effect of service quality on relationship quality in Malaysian automotive market.

The automotive industry in Malaysia is one of the main industries that drive the economy of the country. In line with Malaysia's support to strengthen the competitiveness of local brands, the industry contributes significantly to the Gross Domestic Product (GDP) and the government of Malaysia has set its targets for the following years to increase GDP growth rates. The automotive industry is one of the main industries that contribute to economic GDP and has direct effect on country's economic development (Malaysian Automotive Institute [MAI], 2014). Moreover, the level of competition in 
Malaysian automotive market is high; thus, Malaysian brands should look for the best approaches to face such challenge from foreign brands that are penetrating local market. Therefore, this study is designed to help the industry to achieve its forecast rates for GDP growth in the following years through its outcomes and recommendations. The findings of this study would be beneficial for business practitioners to recognize the role of service quality in enhancing customer relationships and improving overall brand value. The following section reviews the past literature on service quality and explains how it relates with relationship quality.

\section{Literature Review}

\subsection{Relationship Quality}

The increasing interest in brand relationships has significantly contributed to the branding theory in various research contexts (Sahin, Zehir, \& Kitapçi, 2011). A brand represents one of the important means in involving both organizations' staff and their customers in long-lasting relationships (Keller 1993). In particular, developing successful relationships with customers plays a key strategic role in creating and sustaining competitive advantage that ultimately result in improving overall brand success (Palmer, 2002; Peppers \& Rogers 1995). Besides, building good quality relationships with customers are perhaps the most important assets for any organization (Ford \& Hakanson 2006), which may help it to build competitive advantage and increase organizational performance (Hunt, Arnett, \& Madhavaram, 2006). This is because a marketing strategy based on useful and valuable relationships cannot be easily imitated, thereby providing a unique and sustained competitive advantage (Buttle, 1996) and, thus, superior financial performance (Hunt et al., 2006).

Previous literature indicates that several dimensions make up the concept of relationship quality. However, this study focuses on brand trust, brand commitment, and brand satisfaction as the key components of relationship quality. This is because these dimensions are the most cited elements for measuring relationship quality (Hilman, Ghani, \& Hanaysha, 2013). Particularly, the ability of a brand to affect the perceptions of customers on the aforementioned dimensions will as a result enable it to establish good relationships with them and leverage its competitive advantage. Morgan and Hunt (1994) demonstrated that resources like commitment and trust cannot be imitated or purchased. These resources can be used in order to build strong brand equity and create sustainable competitive advantages (Azizi \& Kapak, 2013).

Chaudhuri and Holbrook (2001) referred brand trust to the ability of customers to rely on a brand to deliver what is promised. In business practice, brand trust is considered to be one of the most important antecedents of successful and collaborative relationships between partners. Brand commitment was defined by Morgan and Hunt (1994) as an enduring desire reflected by customers to build and maintain long-lasting relationships with a brand. Moorman, Deshpande, and Zaltman (1993) established that commitment is necessary for establishing successful customer-brand relationships. Finally, brand satisfaction has been regarded as an important dimension of relationship quality, which describes the ability of a brand to please or satisfy its customers through its products or services (Nemati, Khan, \& Iftikhar, 2010). Bitner and Zeithaml (2003) thought about satisfaction as the overall evaluation of customers toward a product or service according to whether that product or service could fulfill their needs and expectations.

Previous studies provided empirical evidence on the positive association between relationship quality dimensions. For example, Osman and Sentosa (2013) examined the effect of satisfaction on trust and found out satisfactions was a strong predictor of trust. Similarly, Kantsperger and Kunz (2010) established that satisfaction was the main predictor of trust; the relationship was statistically significant and positive. Certain scholars (Yeh \& Li, 2009; Walter, Mueller, \& Helfert, 2000) also found similar results indicating that satisfaction had a significant positive effect on trust. Additionally, the effect of trust on brand commitment was supported in empirical literature. For instance, Walter et al., (2003) found that satisfaction was the main determinant of trust, and as a result, trust had significant positive effect on commitment. Patawayati, Zain, Setiawan, and Rahayu (2013) provided an empirical evidence of the significant positive effect of satisfaction on trust. They also reported that trust is positively related to brand commitment. Based on this discussion, the following hypotheses are presented:

$\mathrm{H1}$ : Brand satisfaction has significant positive effect on brand trust.

$\mathrm{H} 2$ : Brand trust has significant positive effect on brand commitment.

\subsection{Service Quality}

Service quality has received significant attention from a number of scholars in past researches. The conceptualization of service quality traces back to 1980s when Parasuraman et al. (1988) developed SERVQUAL model to compare 
customer's perceptions toward the services provided by an organizations with their expectations. Parasuraman et al. (1988) developed five dimensions to measure service quality; tangibility, reliability, responsiveness, assurance, and empathy. In the following years, Bitner (1990) thought about service quality as the overall impression reflected by customers toward the services provided by organizations. In some earlier studies, service quality has been described as the degree to which the provided service fulfils the needs or expectation of customers (Dotchin \& Oakland, 1994). Munusamy, Chelliah, and Mun (2010) demonstrated that providing quality of services is an important component of business related activities that could drive organizational performance and strengthen brand competitiveness.

Providing superior service quality to meet customer satisfaction is one of the most critical and challenging issues for many organizations to maintain their survival in competitive markets (Hung, Huang, \& Chen, 2003). In the theoretical literature, service quality is considered to be a key strategic tool for ensuring product and service differentiation to gain competitive advantage through attracting new customers and increasing market share (Venetis \& Ghauri, 2000). Moreover, service quality provides an inclination among customers' to purchase from the same brand again, to become less price-sensitive, and to recommend others to purchase products from that brand a s a result of their past experiences (Venetis \& Ghauri, 2000). Certain scholars (Bloemer, Ruyter \& Wetzels, 1998; Jones, Beatty, \& Mothersbaugh, 2002) demonstrated that service quality had significant positive relationship with customers' purchase behaviour and brand loyalty.

Certain studies also reported that service quality had significant positive effect on brand trust (Alrubaiee \& Alkaa'ida, 2011; Chang, Chen, \& Lan, 2013; Kassim \& Abdullah, 2010; Osman \& Sentosa, 2013). Su and Fan (2011) in their study found that service quality was significantly and positively related to trust. Similarly, Gefen and Straub, (2006) reported that the service quality has a significant positive effect on trust. Certain scholars (Pepur, Mihanović, \& Pepur, 2013; Wong \& Sohal, 2003) examined the influence of service quality on relationship quality and found out both constructs were positively related. Their findings also indicated that service quality had significant positive influence on relationship quality dimensions; trust, satisfaction, and commitment. A greater supported was confirmed in the study of Ribbink, Van Riel, Liljander, and Streukens (2004) which established that service quality had significant positive effect on brand trust.

Furthermore a number of studies found out service quality had significant positive effect on certain relationship quality dimensions such as brand satisfaction (Alrubaiee \& Alkaa'ida, 2011; Hanaysha, Hilman, \& Warroka, 2011; Khan \& Fasih, 2014; Osman \& Sentosa, 2013). Caniago, Suharyono, Arifin, and Kumadji (2014) also found out service quality significantly influenced customer satisfaction. Saleem and Raja (2014) examined that effect of service quality on satisfaction and found that service quality directly affected customer satisfaction in hotel industry. Furthermore, the effect of service quality on brand commitment was supported in certain previous studies (Auka, Bosire, \& Matern, 2013; Mousavi, Moradi, \& Almasi, 2013). According to Mathieu and Zajac (1990), service quality leads to commitment and it affects customer-brand relationship. Dai, Haried, and Salam (2011) demonstrated that the interactions between a brand and its customer are established according to past experiences, and superior service quality influences customer commitment. Based on the discussion made above, the following hypotheses are presented:

H3: Service quality has significant positive effect on brand satisfaction.

H4: Service quality has significant positive effect on brand trust.

H5: Service quality has significant positive effect on brand commitment.

H6: Service quality has significant positive effect on overall relationship quality.

\section{Methodology}

This study is cross sectional in nature whereby the data was collected from passenger car users at shopping malls in the Northern area of Malaysia; Penang, Kedah, and Perlis. Based on the data obtained from the official department of road and transport in Malaysia, the Northern region of the country covers more than one million of passenger cars on road. Thus, following the suggestions of Krejcei and Morgan (1970) table for sample size determination, this study employed a sample of 384. The designed questionnaire was personally administered to the respondents using systematic sampling technique at shopping malls. To randomize our sample, every $10^{\text {th }}$ leaving customer from each shopping mall was approached at the entrance to participate in this study. The collected data is analyzed using SPSS and structural equation modeling (SEM). Specifically, Cronbach's alpha was calculated using SPSS 19. Then, confirmatory factor analysis, measurement model, and structural model were tested using AMOS 18.

The instrument utilized to measure relationship quality is adapted from past studies with some modifications made to ensure that it would be appropriate to the context of the present study. Particularly, relationship quality is composed of three dimensions: brand satisfaction, brand trust, and brand commitment. The measurement items of brand trust were 
adapted from Ok, Choi, and Hyun (2011) and were selected because they had high reliability with Cronbach's alpha of 0.811 (Hair, Black, Babin, Anderson, \& Tatham, 2010). Moreover, brand commitment was measured using four items adapted from Mohammad (2012). The items were selected because they had an acceptable reliability with Cronbach's alpha of 0.8 (Hair et al., 2010). To measure brand satisfaction, five items were adapted from the study of Zboja and Voorhees (2006). The items were, selected because they exhibited strong construct reliability, ranging from 0.94 to 0.96 (Hair et al., 2010). Finally, the measurement scale of service quality is adapted from the study of Taleghani, Largani, and Mousavian (2011) and it had an acceptable reliability with a Cronbach's alpha value of more than 0.7 .

\section{Analysis of Results}

As stated above, 384 questionnaires were personally distributed to the respondents at shopping malls. But, only 287 were returned back representing $74.7 \%$ of response rate. The respondents' profile indicated that $136(47.4 \%)$ were male and $151(52.6 \%)$ were female. On age profile, it shows that $12 \%$ were 25 years old or less, while most of the respondents (48.8\%) were between 26 and 35 years old. Furthermore, $16 \%$ of the respondents fall in the age category of 36 to 45 years, and only $22.6 \%$ were 46 years or more. Similarly, the respondents' profile indicated that $75.3 \%$ of the participants are Muslims, $4.9 \%$ are Christians, $4.5 \%$ are Hindu, $14.6 \%$ are Buddhists, and only $0.7 \%$ had other religions. Finally, our results revealed that $43.2 \%$ had high school certificate, $21.6 \%$ had diploma, $25.4 \%$ had bachelor degree, $8 \%$ had postgraduate degree, and only $1.7 \%$ had other certificate.

In order to ensure the reliability of measurement scales, both Cronbach's alpha and composite reliability were used. The generated findings based on SPSS indicated that all constructs exceeded the cut-off value of 0.7 as per the suggestions of Hair et al. (2010). Specifically, the Cronbach's alpha of service quality is reported at the value of 0.930 . Additionally, relationship quality and its dimensions achieved the minimum requirement of Cronbach's alpha reliability with values higher than 0.7 ; brand trust (0.920), brand commitment (0.918), and brand satisfaction (0.967). To support the Cronbach's alpha, composite reliability was calculated. Our results indicated that all constructs have acceptable values of composite reliability providing further evidence of existing reliability on the selected scales.

In this study, confirmatory factor analysis (CFA) was conducted to test construct and convergent validity using the measurement model on AMOS. The model was finalized after achieving good fit according to some indicators. The results indicated that the Chi-square was significant $(p$-value $=0.000)$ at 221.729. Other indicators also achieved the recommended cut-off values to fulfil the assumptions of model fit and test for CFA (GFI=0.902, AGFI=0.857, CFI= $0.965, \mathrm{TLI}=0.973, \mathrm{RMSEA}=0.074$ ). To calculate CFA, factor loadings on remaining items of each construct are reported based on standardized regression weight. However, items with values of less than 0.50 were eliminated. Thus, the remaining items have acceptable factor loading values ranging from 0.81 to 0.95 (see Appendix A), and this means that both construct and convergent validity are achieved. Similarly, the test of discriminant validity was conducted according to average variance extracted (AVE) calculations. The findings also demonstrated that AVE values of each construct exceeded 0.50, at the same time are more than the correlation squared, and this provides evidence that discriminant validity is confirmed (Fornell \& Larcker, 1981).

To order to test the hypothesis presented in earlier sections, the structural model was drawn with some indicators to achieve good fit for the data. The final model yielded a significant Chi-square at 226.307 ( $p$-value= 0.000). Furthermore, the value of degree of freedom is equal to 95. Other fit indicators were also used to ensure goodness of model fit $(\mathrm{GFI}=0.900, \mathrm{AGFI}=0.857, \mathrm{CFI}=0.965, \mathrm{TLI}=0.972, \mathrm{RMSEA}=0.74)$. Based on these results, it can be suggested the model reasonably fit the data (Hair et al., 2010). The generated tables based on structural model were used to test the hypotheses and draw conclusions. 


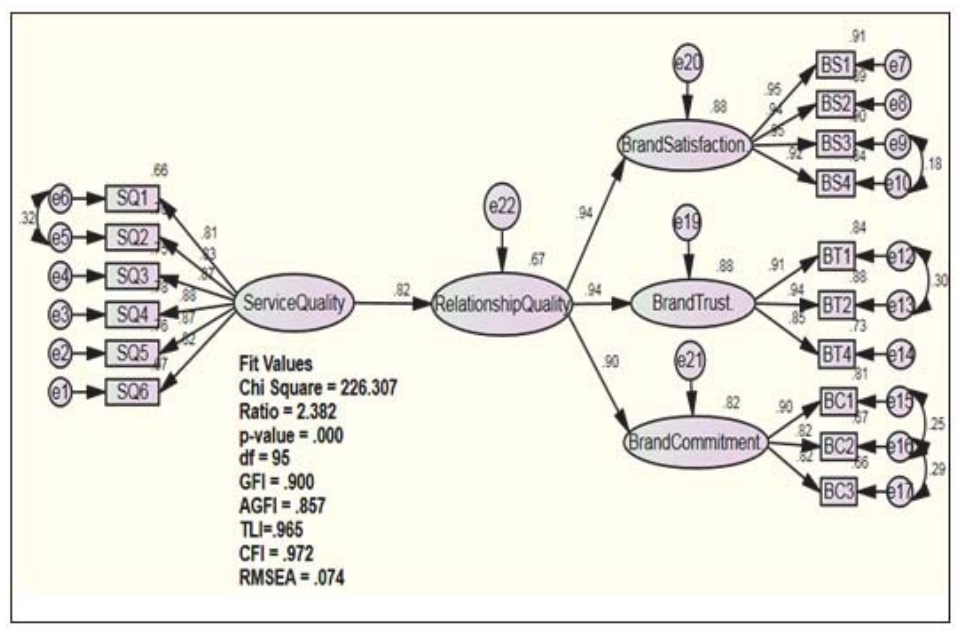

Figure 1: Structural Model

The results shown in Table 1 indicate that satisfaction has significant positive effect on brand trust $(\beta=1.112, C R=$ 14.535, $\mathrm{p}=<0.05)$, hence, $\mathrm{H} 1$ confirmed. Brand trust as a result has significant positive effect on brand commitment $(\beta=$ $1.112, \mathrm{CR}=14.535, \mathrm{p}=<0.05$ ), therefore, $\mathrm{H} 2$ is supported. The findings also proved that service quality has significant positive effect on brand satisfaction ( $\beta=1.112, C R=14.535, p=<0.05$ ) and explained $61.7 \%$ of its total variance, thus, $\mathrm{H} 3$ is supported. The positive effect of service quality on brand trust is also supported ( $\beta=0.873, C R=10.815, p=<0.05$ ), consequently, $\mathrm{H} 4$ is accepted. Moreover, $80.3 \%$ of variance in brand trust is explained by service quality. The findings also revealed that service quality has significant positive effect on brand commitment $(\beta=1.187, C R=14.618, p=<0.05)$ and explains $78.7 \%$ of its variance, therefore, $\mathrm{H} 5$ is accepted. Finally, our results proved that service quality has significant positive effect on overall relationship quality $(\beta=0.076, C R=13.874, p=<0.05)$ and explained $66.8 \%$ of overall variance in relationship quality, which yields support for $\mathrm{H} 6$.

Table 1: Research Findings

\begin{tabular}{lccccc}
\hline Hypothesized Effect & Std. Estimate & S.E. & C.R. & P & Support \\
\hline H1: Brand satisfaction has significant positive effect on brand trust. & .788 & 0.062 & 11.842 & $* \star *$ & Yes \\
H2: Brand trust has significant positive effect on brand commitment. & .775 & 0.079 & 10.104 & $\star \star *$ & Yes \\
H3 Service quality has significant positive effect on brand satisfaction. & 0.785 & 0.075 & 13.781 & $\star \star \star$ & Yes \\
H4: Service quality has significant positive effect on brand trust. & 0.133 & 0.078 & 2.093 & .036 & Yes \\
H5: Service quality has significant positive effect on brand commitment. & 1.143 & 0.090 & 2.011 & .044 & Yes \\
H6: Service quality has significant positive effect on overall relationship quality & 0.817 & 0.075 & 13.552 & $* \star *$ & Yes \\
\hline
\end{tabular}

***: $p<0.001 ; * *: p<0.01 ; *: p<0.05$

\section{Discussion and Conclusion}

This study examined the effect of service quality on relationship quality from customers' perspective in automotive industry. Relationship quality was measured in terms of three components; brand satisfaction, brand trust, and brand commitment. The results revealed that brand satisfaction has significant positive impact on brand trust. This result is consistent with the findings of several previous studies (Kassim \& Abdullah, 2010; Oktora \& Achyar, 2014; Shpëtim, 2012). This means that if customers are satisfied about the products or services provided by a brand, they will as a result develop positive trust toward that brand. The results also indicated that brand trust positively influenced brand commitment. The finding is in line with a number of previous studies (Cho \& Hu, 2009; Rahab \& Supadi, 2012; Suki, 2011) which confirmed that trust positively affected brand commitment. Therefore, it can be said that if customers are satisfied with the services provided by a brand, they will be more willing to deal with that brand again in their future transactions and recommend it to others. Additionally, satisfied customers not only will repurchase the same brand even other alternatives are available at same price, but also they will develop positive word-of-mouth communications and recommend it to others. 
The finding also proved that service quality has significant positive effect on brand satisfaction and it matches with several previous studies (Osman \& Sentosa, 2013; Saleem \& Raja, 2014; Shpëtim, 2012) which confirmed that service quality had positive effect on satisfaction of customers. The managerial implication from this finding is that service quality is very important for building brand satisfaction. In order to successfully satisfy the needs of customers, automotive manufacturers should be professional in dealing with them and develop effective system that could manage to handle any issue faced by them on time. As customers' trust toward a brand has a significant effect on behavioral intentions, their willingness to trust or recommend an automotive brand comes from how well those customers are treated by its staff.

Furthermore, the findings revealed that service quality has significant positive effect on brand trust. Certain scholars provided evidence that service quality positively affected brand trust (Chang et al., 2013; Cho \& Hu, 2009; Chou, 2014; Shpëtim, 2012; Wong \& Sohal, 2003). The result shows that the degree of service quality in organizations would affect brand trust which comes from customers' experiences through dealing with that brand before. Therefore, managers should improve the quality of their services to develop customers' trust. For example, automotive managers can extend the scope of their services and provide training programs to their staff and educate them on how to deal efficiently with customer and handle their issues and complaints. The ability of a brand to fulfil customers' needs as promised may also provides important implications to brand trust. After all, safety and honesty issues are important. Particularly, as purchasing an automotive brands involves high cost, customers are becoming more anxious about the credibility of the manufacturering brand. Therefore, automotive service providers have to create customers' psychological trust through their offerings.

Similarly, our study found out service quality has significant positive effect on brand commitment and it was supported by previous studies (Cho \& Hu, 2009; Dai et al., 2011; Mousavi et al., 2013). This means that providing quality of services to customers can influence brand commitment and customer's personal attachment without creating intentions to switch to others. Automotive managers can use the present findings to enhance automotive customer service strategies that strengthen and improve higher levels of commitment. The managers may wish to use these findings to differentiate themselves from competitors in a competitive automotive marketplace through establishing successful relationship commitment.

The findings also revealed that service quality has significant positive effect on overall relationship quality. The finding was supported by several previous studies (Chang et al., 2012; Patawayati et al., 2013). Thus, automotive managers should clearly understand the important elements of service quality that would significantly improve customerbrand relationships for the sake of strengthening brand performance and competitive advantage. By doing so, automotive brands will have better capabilities to formulate and implement the right strategic plans to enhance customer relationship. The interpretations of the results have the potential to help automotive manufactures in better understanding of how car users may assess the quality of services that could influence their satisfaction, trust, and commitment in various extents. For example, extending the warranty period as Hyundai may improve customer relationships over a long period of time. After sale service and increasing the number of service shops may also influence customers' willingness to maintain their relationships with the brand. Learning such information can help them to effectively use their human and capital resources to develop the best approaches to enhance service quality aspects under certain circumstances.

Although the outcomes of this study are beneficial in understanding the effect of service quality on relationship quality, there are some limitations that should be addressed in future researches. First, this study is limited to testing service quality and relationship quality within a particular sector in Malaysia. Therefore, larger scope is open for future researches on these concepts in other countries. Future researches can also examine other antecedents of relationship quality such as innovation and social media as customers nowadays have many choices to form before purchasing any brand, and their interactions with social media are quiet high. Second, this study was conducted on passenger car users in Northern region of Malaysia. Future research can look into the possibility of targeting respondents from other industry contexts using larger sample. Finally, this study used cross-sectional survey to collect the data. Thus, future studies may wish to implement longitudinal data and qualitative approaches for better understanding of relationship quality antecedents from the perspective of both customers and managers.

\section{References}

Alrubaiee, L., \& Alkaa'ida, F. (2011). The Mediating Effect of Patient Satisfaction in the Patients' Perceptions of Healthcare Quality-Patient Trust Relationship. International Journal of Marketing Studies, 3(1), 103-127.

Auka, D. O., Bosire, J. N., \& Matern, V. (2013). Perceived Service Quality and Customer Loyalty in Retail Banking in Kenya. British Journal of Marketing Studies, 1(3), 32-61.

Azizi, S., \& Kapak, S. J. (2013). Factors Affecting Overall Brand Equity: The Case of Shahrvand Chain Store. Management and Marketing, 11(1), 91-103. 
Bitner, M. J. (1990). Evaluating Service Encounters: The Effects of Physical Surroundings and Employee Responses. Journal of Marketing, 54(2), 69-82.

Bitner, M. J. \& Zeithaml, V. A. (2003). Service Marketing (3rd ed.), Tata McGraw Hill, New Delhi.

Bloemer, J., Ruyter, K., \& Wetzels, M. (1998). On the relationship between perceived service quality, service loyalty and switching costs. International Journal of Industry Management, 9(5), 436-453.

Buttle, F. (1996). Relationship marketing: thoery and practice, Sage Publishing, London.

Caniago, A., Suharyono, Arifin, Z., \& Kumadji, S. (2014). The Effects of Service Quality and Corporate Rebranding on Brand Image, Customer Satisfaction, Brand Equity and Customer Loyalty (Study in Advertising Company at tvOne). European Journal of Business and Management, 6(19), 118-126.

Chang, H. H., Lee, C. H., \& Lai, C. Y. (2012). E-Service quality and relationship quality on dealer satisfaction: Channel power as a moderator. Total Quality Management \& Business Excellence, 23(7-8), 855-873.

Chang, C. S., Chen, S. Y., \& Lan, Y. T. (2013). Service quality, trust, and patient satisfaction in interpersonal-based medical service encounters. BMC health services research, 13(1), 22.

Chaudhuri, A., \& Holbrook, M. B. (2001). The chain of effects from brand trust and brand affect to brand performance: The role of brand loyalty. Journal of Marketing, 65(2), 81-93.

Chou, P. F. (2014). An Evaluation of Service Quality, Trust, and Customer Loyalty in Home-Delivery Services. International Journal of Research in Social Sciences, 3(8), 99-108

Dai, H., Haried, P., \& Salam, A. F. (2011). Antecedents of online service quality, commitment and loyalty. Journal of computer information systems, 52(2), 1-11.

Dotchin, J. A., \& Oakland, J. S. (1994). Total Quality Management in Services Part 2: Service Quality. International Journal of Quality and Reliability Management, 11(3), 27- 42.

Ford, D. \& H. Hakanson (2006). IMP - some things achieved: much more to do, European Journal of Marketing, 40(3/4), 248-58.

Fornell, C., \& Larcker, D. F. (1981). Evaluating structural equation models with unobservable variables and measurement error. Journal of Marketing Research, 18(1), 39-50.

Hair, J. F., Jr., Black, W. C., Babin, B. J., Anderson, R. E., \& Tatham, R. L. (2010). Multivariate Data Analyisis (7th ed.) Upper Saddle River, N.J: Pearson Prentice Hall.

Hilman, H., Ghani, N. H. A., \& Hanaysha, J. (2013). Relationship Quality as a Strategic Tool in Today's Turbulent Business. Australian Journal of Basic and Applied Sciences, 7(14), 478-787.

Hilman, H., \& Hanaysha, J. (2015). The Impact of Country of Origin on Relationship Quality: Empirical Evidence from Automotive Industry. Mediterranean Journal of Social Sciences, 6(2), 165-174.

Hanaysha, J. R. M., Abdullah, H. H., \& Warokka, A. (2011). Service quality and students' satisfaction at higher learning institutions: the competing dimensions of Malaysian Universities' competitiveness. Journal of Southeast Asian Research, 1-10. http://dx.doi.org/ $10.5171 / 2011.855931$

Hung, Y.H., Huang, M.L., \& Chen, K.S. (2003). Service quality evaluation by service quality performance matrix. Total Quality Management and Business Excellence, 14(1), 79-89.

Hunt, S. D., Arnett, \& Madhavaram, S. (2006). The explanatory foundations of relationship marketing theory. Journal of Business \& Industrial Marketing, 21(2), 72-87.

Jones, M. A., Beatty, S. E., \& Mothersbaugh, D. V. (2002). Why customers stay: measuring the underlying dimensions of services switching costs and managing their differential strategic outcomes. Journal of Business Research, 55, 441-450.

Kantsperger, R., \& Kunz, W. H. (2010). Consumer trust in service companies: a multiple mediating analysis. Managing Service Quality: An International Journal, 20(1), 4-25.

Kassim, N., \& Abdullah, N. A. (2010). The effect of perceived service quality dimensions on customer satisfaction, trust, and loyalty in ecommerce settings: a cross cultural analysis. Asia Pacific Journal of Marketing and Logistics, 22(3), 351-371.

Keller, K.L. (1993). Conceptualizing, measuring, and managing customer-based brand equity. Journal of Marketing, 57(1), 1-22.

Khan, M. M., \& Fasih, M. (2014). Impact of Service Quality on Customer Satisfaction and Customer Loyalty: Evidence from Banking Sector. Pakistan Journal of Commerce and Social Sciences, 8(2), 331-354.

Krejcie, R. V., \& Morgan, D. W. (1970). Determining sample size for research activities. Educational and Psychological Measurement, 30, 607610.

Malaysian Automotive Institute (2014). Malaysian government driving auto industry transformation,

Retreived on 8 September, 2014 from: http://mai.org.my/v3/index.php?option=com_k2\&view=item\&id=153:malaysian-government-driving-autoindustry-transformation

Mathieu, J. E., \& Zajac, D. M. (1990). A review and metaanalysis of the antecedents, correlates and consequences of organizational commitment. Psychological Bulletin, 108(2), 171-194.

Mohammad, A. A. S. (2012). The Effect of Brand Trust and Perceived Value in Building Brand Loyalty. International Research Journal of Finance and Economics, 85, 111-126.

Moorman, C., Deshpande, R. \& Zaltman, G. (1993). Factors affecting trust in market research relationships. Journal of Marketing, 57 (January), 81-101.

Morgan, R.M., \& Hunt, S.D. (1994). The commitment-trust theory of relationship marketing. Journal of Marketing, 58(3), 20-38.

Mousavi, S. S., Moradi, A., \& Almasi, M. (2013). The effect of service quality and price on customer commitment (case study: Kermanshah Saman assurance's). International Research Journal of Applied and Basic Sciences, 5(10), 1252-1257.

Munusamy, J., Chelliah, S., \& Mun, H. W. (2010). Service quality delivery and its impact on customer satisfaction in the banking sector in Malaysia. International Journal of Innovation, Management and Technology, 1(4), 398-404.

Nemati, A. R., Khan, K., \& Iftikhar, M. (2010). Impact of Innovation on Customer Satisfaction and Brand Loyalty, A Study of Mobile Phones users in Pakistan. European Journal of Social Sciences, 16(2), 299-306.

Ok, C., Choi, Y. G., \& Hyun, S. S. (2011). Roles of Brand Value Perception in the Development of Brand Credibility and Brand Prestige. Paper 
presented at the International CHRIE Conference-Refereed Track, Event, United States.

Oktora, K., \& Achyar, A. (2014). The Effect of Post-Purchase Perceived-Value towards the Relationship Quality of Hajj and Umrah Travel Agencies in Indonesia. The South East Asian Journal of Management, 8(1), 29-46.

Osman, Z., \& Sentosa, I. (2013). Influence of customer satisfaction on service quality and trust relationship in Malaysian rural tourism. Business Management Quarterly Review, 4(2), 12-25.

Palmer, A. (2002). The Evolution of an Idea: An Environmental Explanation of Relationship Marketing. Journal of Relationship Marketing, 1(1), 7994.

Parasuraman, A., Zeithaml, V. A., \& Berry, L. L. (1988). SERVQUAL: A multiple-item for measuring consumer perceptions of service quality. Journal of Retailing, 64(1), 12-40.

Patawayati, Zain, D., Setiawan, M., \& Rahayu, M. (2013). Patient Satisfaction, Trust and Commitment: Mediator of Service Quality and Its Impact on Loyalty (An Empirical Study in Southeast Sulawesi Public Hospitals). IOSR Journal of Business and Management, 7(6), 1-14.

Peppers, D., \& Rogers, M. (1995). A New Marketing Paradigm: Share of Customer, not Market Share. Managing Service Quality, 5(3), 48-51.

Pepur, S., Mihanović, Z., \& Pepur, M. (2013). Analysis of the effect of perceived service quality to the relationship quality on the business-tobusiness market. Management-Journal of Contemporary Management Issues, (2 (18), 97-109.

Rahab \& Supadi, (2012). Relationship Marketing Model on Customer Commitment: the role Economics, Resources, and Social Content. Accessed on 2 December, 2014 from: http://www.ipedr.com/vol46/024-ICBER2012-N20020.pdf.

Ribbink, D., Van Riel, A. C., Liljander, V., \& Streukens, S. (2004). Comfort your online customer: quality, trust and loyalty on the internet. Managing service quality, 14(6), 446-456.

Saleem, H., \& Raja, N. S. (2014). The Impact of Service Quality on Customer Satisfaction, Customer Loyalty and Brand Image: Evidence from Hotel Industry of Pakistan. Middle-East Journal of Scientific Research, 19(5), 706-711.

Sahin, A., Zehir, C., \& Kitapçi, H. (2011). The Effects of Brand Experiences, Trust and Satisfaction on Building Brand Loyalty; An Empirical Research On Global Brands. Procedia Social and Behavioral Sciences, 24, 1288-1301.

Shpëtim, Ç. (2012). Exploring the Relationships among Service Quality, Satisfaction, Trust and Store Loyalty among Retail Customers. Journal of Competitiveness, 4(4), 16-35.

Su, L., \& Fan, X. (2011). A Study on the Relationships between Service Quality, Satisfaction, Trust and Loyalty among Rural Tourism. Proceedings of the IEEE ICQR, 1413-1417

Suki, N. M. (2011). Assessing patient satisfaction, trust, commitment, loyalty, and doctors' reputation towards doctor services. Pakistan Journal of Medical Sciences, 27(5), 1207-1210.

Taleghani, M., Largani, M. S., \& Mousavian, S. J. (2011). The Investigation and Analysis Impact of Brand Dimensions on Services Quality and Customers Satisfaction in New Enterprises of Iran. Contemporary Marketing Review, 1(6), 1-13.

Tey, Y. S., Brindal, M., Fatimah, M. A., Kusairi, M. N., Ahmad Hanis, I. A. H., \& Suryani, D. (2014). The impact of service quality on business commitment in B2B segment of agribusiness: An exploratory study of HORECA sector in Malaysia. International Food Research Journal, 21(3).

Venetis, K.A., \& Ghauri, P.N. (2000). The importance of service quality on customer retention: an empirical study of business service relationships, Proceedings of the Marketing in a Global Economy Conference, Buenos Aires.

Walter, A., Mueller, T. A., \& Helfert, G. (2000). The impact of satisfaction, trust, and relationship value on commitment: theoretical considerations and empirical results. In IMP Conference Proceedings.

Wong, A., \& Sohal, A. (2003). Service quality and customer loyalty perspectives on two levels of retail relationships. Journal of services marketing, 17(5), 495-513.

Yeh, Y. S., \& Li, Y. M. (2009). Building trust in m-commerce: contributions from quality and satisfaction. Online Information Review, 33(6), 10661086.

Zboja, J. J., \& Voorhees, C. M. (2006). The impact of brand trust and satisfaction on retailer repurchase intentions. Journal of Services Marketing, 20(6), 381-390.

Appendix A: Measurement Scale of Final Items

\begin{tabular}{|l|c|}
\hline Relationship Quality Dimensions & Factor Loadings \\
\hline a. Brand Satisfaction ( $\mathbf{\alpha}=\mathbf{0 . 9 7 3 )}$ & 0.955 \\
\hline I am satisfied with my decision to purchase this car. & 0.944 \\
\hline My choice to buy this car was a wise one. & 0.949 \\
\hline I think that I did the right thing when I bought this car. & 0.917 \\
\hline I am happy that I bought this car. & 0.914 \\
\hline b. Brand Trust (a) 0.939) & 0.937 \\
\hline The car brand I'm using is trustworthy & 0.854 \\
\hline The car I'm using is reliable. & 0.901 \\
\hline The car I'm using is safe. & 0.818 \\
\hline c. Brand Commitment (a= 0.908) & 0.815 \\
\hline I am committed to this car brand. & \\
\hline I am willing to make small sacrifices in order to keep using this car brand. & 0.814 \\
\hline I have made a pledge to stick with this car brand. & 0.834 \\
\hline Service Quality (a= 0.930) & 0.867 \\
\hline This car brand offers excellent service. & 0.881 \\
\hline I feel good about what this car brand offers to its customers. & 0.874 \\
\hline The quality of my interactions with this car brand's employees is good. & 0.819 \\
\hline The physical environment of this car brand's sales centres is one of the best in its industry. \\
\hline The physical environment of this car brand's service centres is one of the best in its industry. \\
\hline This car brand has fair system for the handling of complaints. & \\
\hline
\end{tabular}

